Kumawula, Vol. 3, No.2, Agustus 2020, Hal 189 - 196 DOI: https://doi.org/10.24198/kumawula.v3i2.25723

ISSN 2620-844X (online)

Tersedia online di http://jurnal.unpad.ac.id/kumawula/index

\title{
PENERAPAN PROGRAM “REALISTIS” (REHABILITASI LAHAN KRITIS) SEBAGAI UPAYA PENANGGULANGAN LAHAN KRITIS DI DESA CILELES
}

\author{
In-In Hanidah ${ }^{1 *}$, Revena Denia Putri ${ }^{2}$, Ghoffar Cahya Madani ${ }^{3}$, Risa Anggreini ${ }^{4}$, \\ Sartika Azhari ${ }^{5}$ \\ 1,2,3,4,5 Universitas Padjadjaran \\ *inin@unpad.ac.id
}

\begin{abstract}
ABSTRAK
Lahan kritis disebabkan karena hilangnya produktivitas dan kandungan unsur hara yang berada pada lahan tersebut akibat perilaku manusia ataupun fenomena alam. Program "REALISTIS" memiliki tujuan sebagai program rehabilitasi pada lahan kritis untuk membenahi dan menanggulangi keadaan lahan yang sudah hilang produktivitasnya serta meningkatkan kreativitas masyarakat dalam mengelola lahan kritis di Desa Cileles. Dengan menggunakan metode preparing: menetapkan lokasi lahan kritis untuk pembersihan lahan dan penanaman bibit tanaman palawija, actuating: penyuluhan tentang pentingnya rehabilitasi lahan kritis, dan controlling: monitoring dan evaluasi pada penerapan program "REALISTIS” masyarakat dapat terlibat langsung dalam mewujudkannya. Hasil riset menunjukkna bahwa wilayah Desa Cileles terbagi kedalam 8,85\% kawasan pemukiman, 18,79\% kawasan persawahan, 14,46\% kawasan perkebunan, dan 57,91\% kawasan lahan kritis dengan jenis tanah vulkanik termasuk ke dalam tanah yang cukup subur. Keberhasilan program ini dapat diukur berdasarkan perkembangan tanaman yang tumbuh pada tanah yang sudah ditanami oleh tanaman palawija dengan teknik tumpang sari.
\end{abstract}

\begin{abstract}
Critical land is caused by the loss of productivity and nutrient content in the land due to human behavior or natural phenomena. The "REALISTIC" program aims of being a rehabilitation program on degraded land to improve and overcome the condition of land that has lost its productivity and to increase the creativity of the community in managing degraded land in the Cileles village. By using the method of preparing: determining the location of degraded land to land and planting seedlings of crops, actuating: counseling about the importance of rehabilitation of degraded land, and controlling: monitoring and evaluation of the implementation of the "REALISTIS" program the community can be directly involved in realizing it. The research results show that the area of the Village of Cileles is divided into $8.85 \%$ habitation areas, $18.79 \%$ ricefields areas, $14.46 \%$ plantation areas, and $57.91 \%$ critical land areas with volcanic soil types including into fertile soils. This success of this program can be measured based on the development of plants that grow on land that has been planted by crops using intercropping techniques.
\end{abstract}

Keywords: actuating, cileles; controlling; critical land; preparing; realistis.

\section{PENDAHULUAN}

Desa Cileles merupakan desa yang potensial dikembangkan melalui program rehabilitasi lahan kritis agar lahan yang tidak termanfaatkan dapat menjadi produktif. Banyaknya lahan kosong di wilayah pemukiman penduduk yang tidak termanfaatkan dengan optimal 
mengakibatkan kualitas lingkungan menjadi kurang baik. Sementara berdasarkan hasil analisis kualitatif, lahan kosong tersebut dapat dimanfaatkan menjadi lahan pertanian. Penanaman sayuran dapat menjadi salah satu alternatif untuk memanfaatkan lahan kritis sehingga kebutuhan pangan keluarga dapat terpenuhi secara mandiri(Samijo \& Istiyanti, 2016). Bibit sayuran yang akan ditanam yaitu tanaman yang yang dapat dikonsumsi serta memiliki nilai jual di pasaran, seperti: terong, sawi, bayam, kangkung, tomat, seledri, dan cabai. Penanaman sayuran yang lebih beragam melalui teknik tumpang sari menjadi salah satu alternatif untuk menjaga komposisi unsur hara tanah yang sempat hilang di lahan kritis (Sutrisna et al., 2010). Penanaman yang berhasil dalam penanggulangan lahan kritis dapat mempertahankan kesuburan tanah untuk menyimpan air. Di tengah kondisi harga bahan kebutuhan pokok naik, menanam sayur mayur pada lahan kritis dapat turut membantu penanggulangan lahan kritis dan perekonomian dalam rumah tangga.

Secara umum, lahan di Desa Cileles terbagi menjadi beberapa jenis yaitu, tanah humus, tanah aluvial, tanah laterit, tanah pasir, dan tanah entisol. Desa Cileles berada pada dataran tinggi dan kawasan pegungunan yang tidak aktif secara vulkanik, namun jenis tanah keseluruhan Desa Cileles dapat digolongkan sebagai tanah vulkanik. Di Desa Cileles, wilayah yang memiliki potensi pemanfaatan lahan kritis adalah RW. 01, RW. 04, RW. 05, RW. 08, dan RW. 10. Melalui program "REALSISTIS” diharapkan dapat meningkatkan kehidupan sosial ekonomi masyarakat, meningkatkan produktivitas hasil pertanian, dan meningkatkan kualitas lingkungan menjadi lebih baik sehingga secara tidak langsung menyediakan udara dan melindungi konservasi air.

Berdasarkan latar belakang di atas, penelitian ini bertujuan untuk mengimplementasikan program "REALISTIS” melalui pemetaan lahan kritis di Desa Cileles dan memberikan edukasi pemanfataan lahan kritis kepada masyarakat melalui program penyuluhan.

\section{METODE}

Metode penelitian yang dilakukan diawali dengan observasi langsung ke lapangan untuk mengidentifikasi tingkat kemiringan lereng, plastisitas dan kelembapan tanah. Selanjutnya pengelompokan kelas lereng dengan sifat-sifat proses dan kondisi lahan (Van Zuidam, 1985).

\begin{tabular}{|c|l|}
\hline Kelas Lereng & \multicolumn{1}{|c|}{ Proses, Karakteristik, dan Kondisi Lahan } \\
\hline $0^{\circ}-2^{\circ}$ & Datar atau hamper datar, tidak ada erosi yang besar, dapat diolah dengan mudah \\
$(0-2 \%)$ & dalam kondisi kering. \\
\hline $2^{\circ}-4^{\circ}$ & Lahan memiliki kemiringan lereng landau, bisa terjadi longsor bergerak dengan \\
$(2-7 \%)$ & kecepatan rendah, pengikisan dan erosi akan meninggalkan bekas yang sangat \\
\hline $4^{\circ}-8^{\circ}$ & dalam. \\
\hline
\end{tabular}




\begin{tabular}{|c|l|}
\hline$(7-15 \%)$ & bergerak dengan kecepatan rendah, sangat rawan terhadap erosi. \\
\hline $8^{\circ}-16^{\circ}$ & Lahan memiliki kemiringan lereng yang curam, rawan terhadap bahaya longsor, \\
$(15-30 \%)$ & dan erosi alur. \\
\hline $16^{\circ}-35^{\circ}$ & Lahan memiliki kemiringan lereng yang curam sampai terjal, sering terjadi erosi \\
$(30-70 \%)$ & dan Gerakan tanah dengan kecepatan yang perlahan-lahan. Daerah rawan erosi \\
& dan longsor. \\
\hline $35^{\circ}-55^{\circ}$ & Lahan memiliki kemiringan lereng yang terjal, sering ditemukan singkapan \\
$(70-140 \%)$ & batuan, rawan terhadap erosi. \\
\hline$>55^{\circ}$ & Lahan memiliki kemiringan lereng yang terjal, singkapan batuan muncul \\
$(>140 \%)$ & dipermukaan, rawan terhadap longsor batuan. \\
\hline
\end{tabular}

Kemiringan lereng didapatkan dari hasil pengukuran lereng menggunakan klinometer baik menggunakan klinometer yang dilengkapi kompas geologi. Kemudian menentukan tingkat plastisitas tanah berdasarkan acuan sebagai berikut (Hunt, 2005):

\begin{tabular}{|c|c|c|c|c|c|}
\hline $\begin{array}{l}\text { Tingkat } \\
\text { plastisitas }\end{array}$ & PI & $\begin{array}{l}\text { Identifikasi } \\
\text { (Burmister } \\
\text { System) }\end{array}$ & $\begin{array}{l}\text { Diameter } \\
\text { gulungan } \\
\text { terkecil } \\
(\mathrm{mm})\end{array}$ & Test di lapangan & $\begin{array}{c}\text { Rentang } \\
\text { batas cair }\end{array}$ \\
\hline Non-plastis & 0 & Lanau & None & $\begin{array}{l}\text { Tanak jika digulung-gulung } \\
\text { sepanjang } 40 \mathrm{~mm} \text {, tebal } 6 \mathrm{~mm} \text { tidak } \\
\text { bisa terbentuk }\end{array}$ & - \\
\hline $\begin{array}{l}\text { Agak } \\
\text { plastis } \\
\text { (slightly } \\
\text { plastic) }\end{array}$ & $1-5$ & $\begin{array}{c}\text { Lanau } \\
\text { lempungan }\end{array}$ & 6 & \multirow{2}{*}{$\begin{array}{l}\text { Tanah dapat digulung sepanjang } 40 \\
\text { mm dengan tebal } 6 \text { mm dan dapat } \\
\text { menahan beratnya sendiri, tetapi bila } \\
\text { tebalnya } 4 \mathrm{~mm} \text {, tanah menjadi tidak } \\
\text { dapat menahan beratnya sendiri. }\end{array}$} & $0-35 \%$ \\
\hline Rendah & $5-10$ & $\begin{array}{l}\text { Lanau dan } \\
\text { lempung }\end{array}$ & 3 & & \\
\hline $\begin{array}{l}\text { Sedang / } \\
\text { Semi } \\
\text { plastis } \\
\text { (moderately } \\
\text { plastic) }\end{array}$ & $10-20$ & $\begin{array}{l}\text { Lempung } \\
\text { dan lanau }\end{array}$ & 1.5 & $\begin{array}{l}\text { Tanah dapat dibentuk menjadi } \\
\text { gulungan sepanjang } 40 \mathrm{~mm} \text {, setebal } 4 \\
\text { mm dan dapat menahan beratnya } \\
\text { sendiri, tapi bila tebalnya } 2 \text { mm tidak } \\
\text { dapat menahan beratnya sendiri. }\end{array}$ & $\begin{array}{c}35 \%- \\
50 \%\end{array}$ \\
\hline Tinggi & $20-40$ & $\begin{array}{l}\text { Lempung } \\
\text { lanauan }\end{array}$ & 0.8 & & \\
\hline $\begin{array}{l}\text { Sangat } \\
\text { tinggi (very } \\
\text { plastic) }\end{array}$ & $>40$ & Lempung & 0.4 & $\begin{array}{l}\text { Tenaha dapat dibentuk menjadi } \\
\text { gulungan sepanjang } 40 \mathrm{~mm} \text {, setebal } 2 \\
\text { mm serta dapat menahan beratnya } \\
\text { sendiri. }\end{array}$ & $\begin{array}{c}50 \%- \\
90 \%\end{array}$ \\
\hline
\end{tabular}

Penentuan kandungan air berdasarkan pengelompokan kondisi sebagai berikut (Kurnia et al., 2004):

\begin{tabular}{|l|l|}
\hline \multicolumn{1}{|c|}{ Kondisi } & \multicolumn{1}{c|}{ Deskripsi } \\
\hline Kering (Dry) & $\begin{array}{l}\text { Warna lebih muda daripada kondisi pada saat keadaan lembab. Pasir menjadi } \\
\text { lepas (loose), tanah lanau menjadi getas (brittle) dan bila pecah menjadi abu. } \\
\text { Tanah lempung cenderung akan retak-retak dan tidak dapat dipecahkan oleh } \\
\text { jari tangan. }\end{array}$ \\
\hline $\begin{array}{l}\text { Agak lembab } \\
\text { (Sligthly Moist) }\end{array}$ & Terletak pada gradasi antara keadaan kering dan keadaan lembab. \\
\hline Lembab (Moist) & $\begin{array}{l}\text { Alur kelembapan, cenderung memperlihatkan rentang perubahan warna. Tidak } \\
\text { pada kondisi basah atau kondisi kering. }\end{array}$ \\
\hline $\begin{array}{l}\text { Sangat lembab } \\
\text { (Very Moist) }\end{array}$ & Gradasi antara kondisi lembab dan kondisi basah. \\
\hline Basah (Wet) & Lapisan tipis air terlihat pada butirannya. Gejala rembesan. \\
\hline
\end{tabular}


Penentuan lahan kritis dilakukan dengan pemetaan sebaran lahan yang dilakukan pada lokasi tertentu disetiap RW kemudian dibuat menggunakan Software ArcMap.

Tahap selanjutnya adalah penyebaran informasi menggunakan metode PRA (Partisipatory Rural Appraisal) dengan melibatkan masyarakat melalui penyuluhan dan pendampingan (Ishak \& Sandrawati, 2012). Metode ini berguna untuk meningkatkan pemahaman masyarakat mengenai lahan kritis. Penyuluhan yang kami lakukan bertujuan untuk menyadarkan masyarakat akan adanya kemungkinan kesalah pahaman mereka mengenai lahan kritis. Selain pendidikan masyarakat berupa penyuluhan, kami juga melakukan pelatihan kepada masyarakat berupa demonstrasi rehabilitasi lahan kritis dengan cara menanam tumbuhan palawija yang dapat meningkatkan unsur hara dalam tanah.

\section{HASIL DAN PEMBAHASAN}

Berdasarkan hasil riset diperoleh hasil berupa data lahan-lahan yang tidak dipergunakan sebagaimana fungsinya yaitu kemiringan lereng yang memiliki sudut antara $25^{\circ}$ hingga $45^{\circ}$ bahkan di RW 01 kemiringannya hampir 50 sehingga dikategorikan ke dalam lereng curam hingga terjal. Tingkat plastisitas dari uji lapangan didapatkan hasil lintingan tanah sepanjang $40 \mathrm{~mm}$ dengan tebal 4 mm ini menunjukan bahwa tanah di daerah cileles memiliki kondisi agak plastis, sehingga tanah tidak dapat menahan bebannya sendiri. Apabila dihubungkan dengan kemiringan lereng yang curam hingga terjal, daerah ini rentan terhadap bencana longsor yang merupakan salah satu ciri dari lahan kritis. Sedangkan untuk tingkat kelembaban, tanah di daerah cileles menunjukan kondisi yang bervariasi yaitu dari kering hingga agak lembab.

Berdasarkan interpretasi dalam peta Kawasan lahan Desa Cileles, 8,85\% lahan digunakan untuk kawasan pemukiman, 18,79\% digunakan untuk kawasan persawahan, 14,46\% digunakan untuk kawasan perkebunan, dan 57,91\% merupakan kawasan lahan kritis. Pada bagian timur koordinat

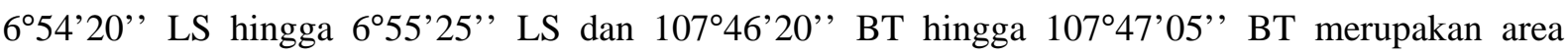

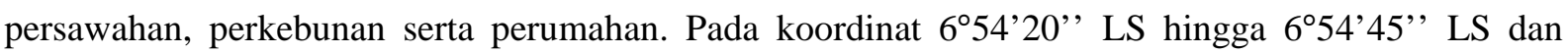

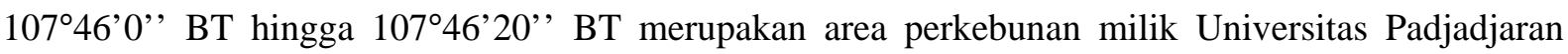

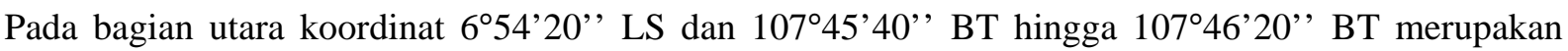
area proyek jalan bebas hambatan cisumdawu phase 2 dan pada bagian barat koordinat 654'20'" LS hingga 6 $6^{\circ} 5^{\prime} 0^{\prime \prime}$ LS dan 10746’0’' BT merupakan Kawasan Bandung Giri Golf and Resort. Proyeksi peta disajikan pada Gambar 1. 


\section{Gambar 1. Peta Kawasan Lahan Desa Cilles, Kec. Jatinangor, Kab. Sumedang, Jawa Barat}

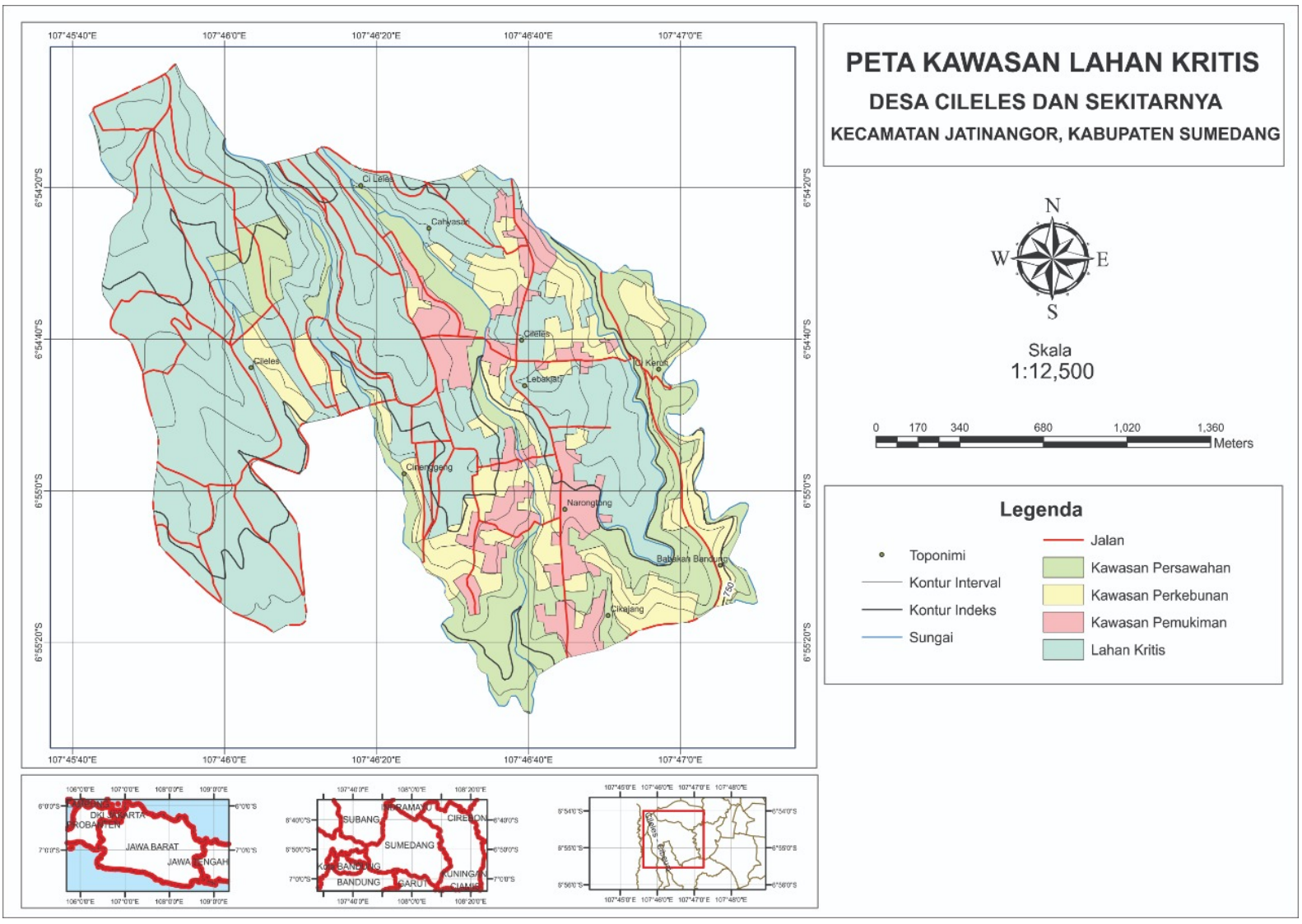

Lahan yang tergolong kritis tersebut dapat berupa: (a) tanah gundul yang tidak bervegetasi sama sekali; (b) ladang alang-alang atau tanah yang ditumbuhi semak belukar yang tidak produktif; (c) areal berbatu-batu, berjurang atau berparit sebagai akibat erosi tanah; (d) tanah yang kedalaman solumnya sudah tipis sehingga tanaman tidak dapat tumbuh dengan baik; (e) tanah yang tingkat erosinya melebihi erosi yang diijinkan (Widyaningtyas et al., 2016). Berdasarkan metode yang digunakan didapatkan hasil berupa data lahan-lahan yang tidak dipergunakan sebagaimana fungsinya.

Berdasarkan peta geologi regional lembar bandung (Quartz12, 2018), Desa Cileles memiliki jenis tanah vulkanik muda. Hal ini terlihat dari komponen batuannya yang terdiri dari tuff halus, lava dan breksi vulkanik. Tanah vulkanik termasuk ke dalam tanah yang cukup subur. Karena tanah ini berasal dari letusan gunung api yang masih berumur muda, jadi masih berupa grain atau butiran belum mengalami kompaksi dan litifikasi atau proses pembatuan.

Pengembangan informasi penggunaan lahan selama beberapa dekade terakhir tidak hanya berorientasi pada penggunaan lahan tapi juga mengarah pada fungsi sosial ekonomi lahan. Untuk meningkatkan pemahaman tentang hubungan penggunaan lahan dan tutupan lahan, maka penggunaan lahan harus dikaitkan dengan aktivitas manusia, khususnya dari segi ekonomi (Anasiru, 2018). 


\section{Gambar 2. Lahan kritis di beberapa RW Desa Cileles}
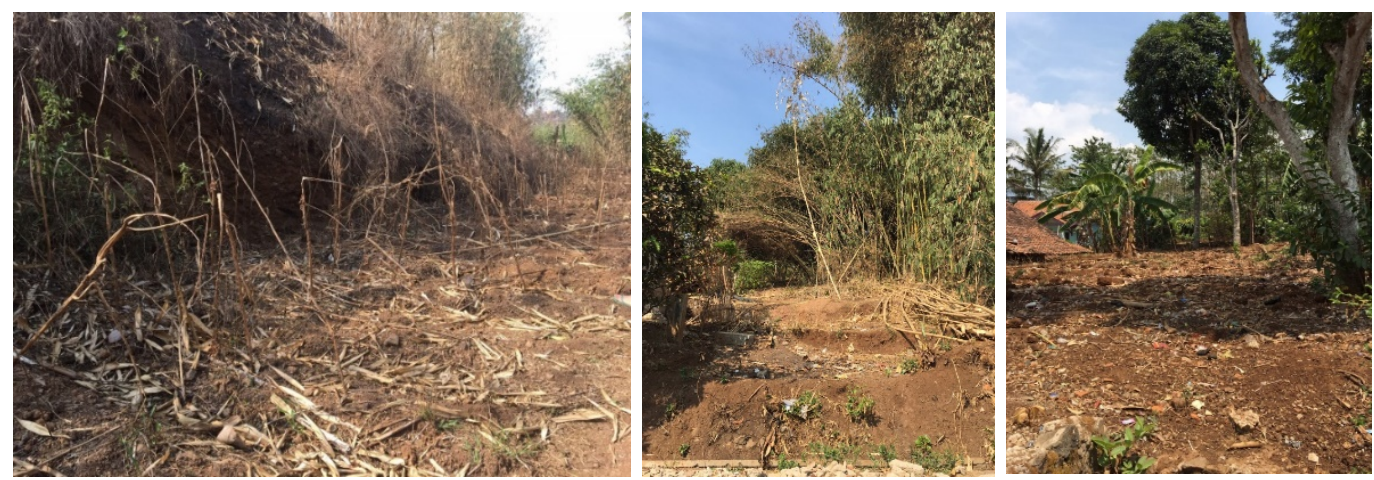

Berdasarkan kelengkapan hasil observasi dan analisis maka tahap selanjutnya melakukan sosialisasi kepada masyarakat Desa Cileles melalui penyuluhan tentang pemanfaatan lahan-lahan kosong yang tidak produktif tersebut atau disebut sebagai lahan kritis. Masyarakat Desa Cileles belum mengethui penggunaan istilah lahan kritis dan belum mengetahui cara merehabilitasi lahan kritis. Tahap pertama dapat dilakukan dengan cara membersihkan lahan yang masih tertutup sampah dan tanaman belukar, kemudian dilakukan penanaman dengan tanaman palawija.

\section{Gambar 2. Kegiatan Penyuluhan Pemanfaatan Lahan Kritis}
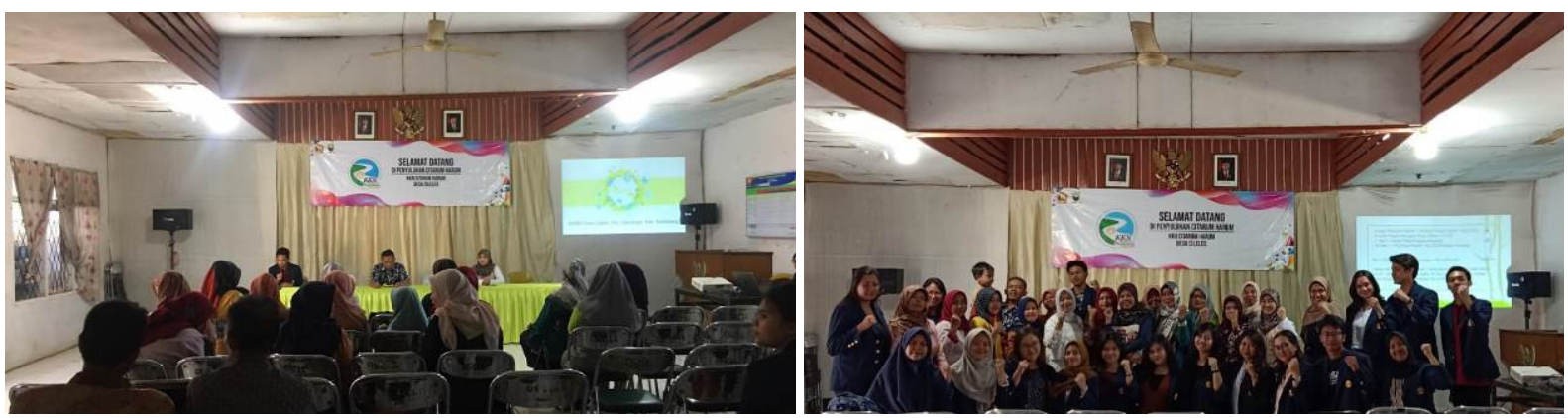

Identifikasi dan pemetaan lahan kritis dilakukan melalui proses tumpang tindih (overlay) dalam operasi Sistem Informasi Geografis (SIG) terhadap peta-peta tematik (data sekunder) yang ada yaitu peta penutupan lahan, peta kemiringan lereng, peta tingkat bahaya erosi, peta pengelolaan lahan (peta manajemen dan peta produktivitas), erosivitas hujan (R), erosi yang diperbolehkan (Edp) dan erodibilitas (K) (Indrihastuti et al., 2017).

Tanah yang ditanami palawija umumnya memiliki kualitas yang sangat baik dan setelah ditanami tanaman palawija jenis kacang akan semakin subur. Karena palawija jenis kacang mengandung nitrat dan nitrit dari daur nitrogen di alam. Ini sangat bagus jika di musim berikutnya ditanami jenis tanaman non-palawija seperti terong, tomat, cabai, tanaman rempah, bawah merah, bawah putih, dan lainnya. Palawija merupakan salah satu komponen untuk melakukan rotasi tanaman. Dimana petani melakukan rotasi tanaman dengan menanam padi yang diselingi palawija untuk memutus siklus hidup hama tikus. Rotasi tanaman terbukti meningkatkan produktivitas hasil pertanian setempat. 
Perbedaan metode dan parameter yang dipergunakan untuk menentukan klasifikasi lahan kritis dapat mengakibatkan perbedaan hasil klasifikasi dan luas lahan kritis yang diperoleh, atau hal tersebut memang disebabkan oleh adanya peningkatan klasifikasi lahan dari yang sebelumnya kritis menjadi tidak kritis (Widmantara et al., 2016). Berdasarkan observasi lapangan di wilayah Desa Cileles, diperkirakan penurunan luasan lahan kritis tersebut tidak terlepas dari perubahan jenis tanaman yang dibudidayakan. Pada beberapa daerah di Desa Cileles dahulu masyarakatnya lebih suka menanam tanaman musim (palawija) pada musim penghujanan, sedangkan pada musim kemarau lahan dibiarkan begitu saja sehingga tampak gundul dan gersang.

Logika ilmiah untuk pembuatan kawasan prioritas perbaikan DAS (konservasi) adalah daerah yang mempunyai nilai koefisien aliran (CN) rendah dan merupakan lahan kritis. Pada area yang nilai CN nya rendah berarti daerah tersebut merupakan daerah resapan, kemudian apabila merupakan lahan kritis, kawasan tersebut diprioritaskan untuk dikonservasi (Daruati D. Apip, 2017).

\section{SIMPULAN}

1. Hasil observasi dan pemetaan sebaran lahan menggunakan Software ArcMap dapat diinterpretasikan Kawasan Desa Cileles memiliki 57,91\% kawasan lahan kritis dengan jenis tanah vulkanik yang memiliki potensi besar untuk dijadikan lahan pertanian.

2. Penyebaran informasi mengenai luas wilayah lahan kritis, potensi pemanfaatakan, dan kondisi hara tanah melalui penyuluhan memberikan wawasan baru untuk masyarakat Desa Cileles.

\section{UCAPAN TERIMAKASIH}

Ucapan terimakasih kami sampaikan kepada Rektor Universitas Padjadjaran yang telah menyelenggarakan program Kuliah Kerja Nyata (KKN) Citarum Harum.

\section{DAFTAR PUSTAKA}

Anasiru, R. H. (2018). Analisis Spasial Dalam Klasifikasi Lahan Kritis Di Kawasan Sub-Das Langge Gorontalo. Informatika Pertanian, 25(2), 261. https://doi.org/10.21082/ip.v25n2.2016.p261272

Daruati D. Apip. (2017). Integrasi Spasial Daya Serap Tanah Dan Lahan Kritis Untuk Penentuan Lokasi Prioritas Perbaikan Das. Limnotek Perairan Darat Tropis Di Indonesia, 24(1), 1-14.

Hunt, R. E. (2005). Geotechnical Engineering Investigation Handbook (T. \& F. Group (ed.); second). CRC Press.

Indrihastuti, D., Murtilaksono, K., \& Tjahjono, B. (2017). Analisis Lahan Kritis Dan Arahan Rehabilitasi Lahan Dalam Pengembangan Wilayah Kabupaten Kendal Jawa Tengah. Tataloka, 18(4), 222. https://doi.org/10.14710/tataloka.18.4.222-239

Ishak, M., \& Sandrawati, A. (2012). Aplikasi Teknologi Tepat Guna Dalam Pengelolaan Lahan Kritis. 
Jurnal Aplikasi Ipteks Untuk Masyarakat, 1(1), 57-63. https://doi.org/10.24198/dharmakarya

Kurnia, U., Achmad, R., \& Ai, D. (2004). Teknoligi Konservasi Tanah pada Lahan Kering Berlereng (D. Supardi (ed.)). Pusat Penelitian dan Penelitian Tanah dan Agroklimat (Puslitbangtanak). http://balittanah.litbang.deptan.go.id

Quartz12, M. (2018). Peta Geologi Regional Lembar Jawa Barat.

https://indogeologist.blogspot.com/2018/07/download-peta-geologi-regional-lembar-jawabarat-lengkap.html?m=1

Samijo, G. S., \& Istiyanti, E. (2016). 13. Berdikari: Jurnal Inovasi Dan Penerapan IPTEK, 4(1), 1322. https://doi.org/https://doi.org/10.18196/bdr.412

Sutrisna, N., Sitorus, S., Pramudya, B., \& Harianto, H. (2010). Alternatif Model Usahatani Konservasi Tanaman Sayuran Di Hulu Sub-DAS Cikapundung. Jurnal Hortikultura, 20(3), 223-240. https://doi.org/10.21082/jhort.v20n3.2010.p

Van Zuidam, R. A. (1985). Aerial Photo - Interpretation in Terrain Analysis and Geomorphologic Mapping. Smith Publisher ITC.

Widmantara, I. M. A., Treman, I. W., \& Suryadi, M. (2016). PEMETAAN LAHAN KRITIS DI KECAMATAN BANJAR, KABUPATEN BULELENG. Jurnal Pendidikan Geografi, 1(4), 53.

Widyaningtyas, A., Asmaranto, R., \& Lufira, R. D. (2016). Studi Pemetaan Lahan Kritis di SUB DAS Kali Gunting Kabupaten Jombang. Brawijaya. 